\title{
Palaeococcus ferrophilus gen. nov., sp. nov., a barophilic, hyperthermophilic archaeon from a deep-sea hydrothermal vent chimney
}

\author{
Ken Takai, ${ }^{1 \dagger}$ Akihiko Sugai, ${ }^{2}$ Toshihiro Itoh ${ }^{2}$ and Koki Horikoshi ${ }^{1}$
}

Author for correspondence: Ken Takai. Tel: +1 509373 3386. Fax: +1 5093761321.

e-mail:ken.takai@pnl.gov

1 Deep-sea Micro-organisms Research Group (DEEPSTAR), Japan Marine Science and Technology Center (JAMSTEC), 2-15 Natsushima-cho, Yokosuka 237-0061, Japan

2 Division of Chemistry, Center for Natural Science, Kitasato University, 1-15-1 Kitasato, Sagamihara, Kanagawa 228-8555, Japan

\begin{abstract}
A novel barophilic, hyperthermophilic archaeon was isolated from a deep-sea hydrothermal vent chimney at the Myojin Knoll in the Ogasawara-Bonin Arc, Japan. The cells were found to be irregular cocci and motile with multiple polar flagella. Growth was observed between 60 and $88^{\circ} \mathrm{C}$ (opt. $83^{\circ} \mathrm{C} ; 30 \mathrm{~min}$ doubling time), pH 4.0 and 8.0 (opt. pH 6.0), 20 and $73 \mathrm{~g}$ sea salts $\mathrm{I}^{-1}$ (opt. $47 \mathrm{~g}$ $\mathrm{I}^{-1}$ ) and 0.1 and $60 \mathrm{MPa}$ (opt. $30 \mathrm{MPa}$ ). The isolate was a strictly anaerobic chemoorganotroph capable of utilizing proteinaceous substrates such as yeast extract, peptone, tryptone and casein in the presence of elemental sulfur or ferrous iron. The G+C content of the genomic DNA was $53.5 \mathrm{~mol} \%$. Phylogenetic analysis based on 16S rDNA sequences indicated that the isolate was a member of an ancient lineage of the Thermococcales that diverged prior to the formation of the two genera Thermococcus and Pyrococcus. On the basis of the physiological and molecular properties of the new isolate, the name Palaeococcus ferrophilus gen. nov., sp. nov. is proposed. The type strain is strain DMJ' ( = JCM 10246').
\end{abstract}

Keywords: hyperthermophilic archaeon, barophilic, Thermococcales, deep-sea hydrothermal vent

\section{INTRODUCTION}

Since the discovery of deep-sea hydrothermal vents in 1977, a number of hyperthermophiles have been isolated from various sites in deep-sea environments (Prieur et al., 1995). These hyperthermophiles are physiologically and phylogenetically diverse groups of micro-organisms and include members of both the bacterial and archaeal domains (Jones et al., 1983; Fiala et al., 1986; Jannasch et al., 1988; Huber et al., 1989, 1997; Pledger \& Baross, 1989, 1991; Burggraf et al., 1990; Stetter et al., 1990; Pley et al., 1991; Gonzalez et al., 1995, 1998; Godfroy et al., 1996, 1997; Antoine et al., 1997; Blöchl et al., 1997; Canganella et al., 1997). Members of the Thermococcales are the most frequently isolated hyperthermophiles and these organisms are regarded as the major decomposers of organic matter within marine hot-water ecosystems (Zillig et al., 1983; Fiala \& Stetter, 1986; Miroshni-

\footnotetext{
† Present address: Pacific Northwest National Laboratory, PO Box 999, Mail stop P7-50, Richland, WA 99352, USA.

The GenBank/EMBL/DDBJ accession number for the $16 \mathrm{~S}$ rDNA sequence of strain $D M J^{\top}$ is $A B 019239$.
}

chenko et al., 1989; Pledger \& Baross, 1989, 1991; Neuner et al., 1990; Gonzalez et al., 1995, 1998; Godfroy et al., 1996, 1997; Antoine et al., 1997; Canganella et al., 1997). They are strictly anaerobic, obligately heterotrophic micro-organisms capable of using complex substrates for growth, such as yeast extract, peptone, bacterial and archaeal cell homogenates and polymers such as casein, gelatin, starch and chitin. Their growth is also strongly associated with the reduction of elemental sulfur $\left(\mathrm{S}^{0}\right)$.

It has been generally considered that sulfur reduction played an important role in the early microbial respiration system, because most ancient lineages of micro-organisms are anaerobic, sulfur-reducing hyperthermophiles, including members of the Thermococcales (Achenbach-Richter et al., 1987). However, it seems likely that iron was more frequently used in early microbial metabolism in the light of the geochemical properties of the habitats of hyperthermophiles (Walker, 1987; Ehlich, 1990; Cairns-Smith et al., 1992; Seyfried \& Mottl, 1995). Hafenbradl et al. (1996) isolated the first hyperthermophilic archaeon capable of oxidizing ferrous iron anaerobically at neutral $\mathrm{pH}$, from a shallow marine hydrothermal vent 
environment. In addition, Vargas et al. (1998) have demonstrated that various hyperthermophilic archaea and bacteria can reduce ferric iron and conserve energy to support their growth. These findings are viewed as significant microbiological evidence of the importance of iron as the primary electron donor/acceptor element on the early Earth, and studies focusing on the isolation and cultivation of ferric-iron-reducing thermophilic bacteria have also supported the importance of iron in early microbial metabolism (Slobodkin et al., 1997; Slobodkin \& Wiegel, 1997).

In this study, we succeeded in the isolation and cultivation of a novel hyperthermophilic archaeon from a black smoker chimney in an area with deep-sea hydrothermal vents at the Myojin Knoll in the Ogasawara-Bonin Arc, Japan. This organism displayed an absolute requirement for either elemental sulfur $\left(\mathrm{S}^{0}\right)$ or ferrous iron $\left(\mathrm{Fe}^{2+}\right)$ for growth. Ferrous iron seemed to be necessary for fermentative metabolism. Phylogenetic analysis based on 16S rRNA sequences indicated that the isolate is a member of a deep-branching lineage of the Thermococcales, placed prior to the divergence between two genera Thermococcus and Pyrococcus. We describe the characterization of this new isolate and propose the new genus name Palaeococcus.

\section{METHODS}

Sample collection. A sample from a black smoker chimney was obtained from the hydrothermal field at Myojin Knoll in the Ogasawara Trough, Japan $\left(32^{\circ} 06 \cdot 208^{\prime} \mathrm{N}, 139^{\circ}\right.$ $52 \cdot 004^{\prime} \mathrm{E}$ ) at a depth of $1338 \mathrm{~m}$ by means of the manned submersible Shinkai 2000 in a dive (dive \#1007) performed in May 1998. The tip of the chimney was brought to the sea surface in a sample box and immediately frozen at $-85^{\circ} \mathrm{C}$. The sample was stored at $-85^{\circ} \mathrm{C}$ prior to incubation.

Enrichment and purification. Portions of the thawed and fractured sample were used to inoculate a series of media including MJYP* medium (described below), which was based on MJYP medium and supplemented with $20 \mathrm{mM}$ $\mathrm{NaNO}_{3}$ and $5 \mathrm{mM} \mathrm{FeSO}$ as possible energy sources or factors supporting growth, and the cultures were incubated at 75,84 or $95^{\circ} \mathrm{C}$. All tubes of MJYP* medium inoculated with portions of the chimney sample became turbid after $2 \mathrm{~d}$ incubation at 75 or $84{ }^{\circ} \mathrm{C}$ and each contained highly motile, irregular cocci. In order to obtain a pure culture, the dilutionto-extinction technique was employed (Baross, 1995). After the cell density of the enrichment culture had reached approximately $10^{8}$ cells $\mathrm{ml}^{-1}, 10$ separate dilution series were prepared in which five 1:10 dilutions of the culture were made, followed by twenty $1: 2$ dilutions. Each dilution was made in MJYP* medium and the cultures were incubated for at least $4 \mathrm{~d}$ at $84^{\circ} \mathrm{C}$. The culture in the tube showing growth at the highest dilution was designated strain $\mathrm{DMJ}^{\mathrm{T}}$.

Sources of organisms. Pyrococcus furiosus (DSM 3638 ), Thermococcus celer (DSM 2476'), 'Thermococcus litoralis' $\left(\right.$ DSM $5473^{\mathrm{T}}$ ), Thermococcus stetteri (DSM 5262 ) and Sulfolobus acidocaldarius (DSM 639 ${ }^{\mathrm{T}}$ ) were purchased from the Japan Collection of Microorganisms (JCM). 'Pyrococcus abyssi' (strain GE5), Thermococcus peptonophilus (JCM 9653 ${ }^{\mathrm{T}}$ ) and Thermococcus profundus (JCM 9378 ${ }^{\mathrm{T}}$ ) were obtained from the culture collection of our institute.
Thermococcus aggregans (JCM 10137 ) and Thermococcus guaymasensis (JCM 10136 ) were kindly provided by Francesco Canganella (University of Tusia, Vierbo, Italy). Rhodothermus obamensis (JCM 9785 ) was provided by Yoshihiko Sako (Kyoto University, Kyoto, Japan) (Sako et al., 1996) and Thermaerobacter marianensis (JCM 10246 ${ }^{\mathrm{T}}$ ) was isolated by us (Takai et al., 1999).

Culture media and conditions. The new isolate was routinely cultivated in MJYP* medium, which was based on MJYP medium [containing $2 \mathrm{~g}$ yeast extract, $2 \mathrm{~g}$ Trypticase peptone, $0.5 \mathrm{~g} \mathrm{Na}_{2} \mathrm{~S} .9 \mathrm{H}_{2} \mathrm{O}$ and $1 \mathrm{mg}$ resazurin $\mathrm{I}^{-1} \mathrm{MJ}(-\mathrm{N})$ synthetic sea water] and supplemented with $20 \mathrm{mM} \mathrm{NaNO}$ and $5 \mathrm{mM} \mathrm{FeSO}_{4}$. When $20 \mathrm{mM} \mathrm{NaNO}$ and $3 \%(\mathrm{w} / \mathrm{v})$ elemental sulfur $\left(\mathrm{S}^{0}\right)$ were added to MJYP medium, this was defined as MJYPS medium. MJ $(-\mathrm{N})$ synthetic sea water consists of $\left(1^{-1}\right): \mathrm{NaCl}, 30.0 \mathrm{~g} ; \mathrm{K}_{2} \mathrm{HPO}_{4}, 0.14 \mathrm{~g}$; $\mathrm{CaCl}_{2} \cdot 2 \mathrm{H}_{2} \mathrm{O}, 0 \cdot 14 \mathrm{~g} ; \mathrm{MgSO}_{4} \cdot 7 \mathrm{H}_{2} \mathrm{O}, 3 \cdot 4 \mathrm{~g} ; \mathrm{MgCl}_{2} \cdot 6 \mathrm{H}_{2} \mathrm{O}$, $4 \cdot 18 \mathrm{~g} ; \mathrm{KCl}, 0.33 \mathrm{~g} ; \mathrm{NiCl}_{2} \cdot 6 \mathrm{H}_{2} \mathrm{O}, 0.5 \mathrm{mg} ; \mathrm{Na}_{2} \mathrm{SeO}_{3} .5 \mathrm{H}_{2} \mathrm{O}$, $0.5 \mathrm{mg}$; $\mathrm{Fe}\left(\mathrm{NH}_{4}\right)_{2}\left(\mathrm{SO}_{4}\right)_{2} \cdot 6 \mathrm{H}_{2} \mathrm{O}, 0.01 \mathrm{~g}$; trace mineral solution, $10 \mathrm{ml}$ (Balch et al., 1979). To prepare MJYP* medium, $2 \mathrm{~g}$ yeast extract, $2 \mathrm{~g}$ Trypticase peptone and $1 \mathrm{mg}$ resazurin were dissolved in 1 litre of $\mathrm{MJ}(-\mathrm{N})$ synthetic sea water and the medium was autoclaved. Thereafter, the medium was degassed with $100 \% \mathrm{~N}_{2}$ and was completed by adding separately prepared anaerobic solutions of $\mathrm{NaNO}_{3}$ (degassed with $100 \% \mathrm{~N}_{2}$ and autoclaved; $\mathrm{pH} 7 \cdot 0$ ), iron sulfate (degassed with $100 \% \mathrm{~N}_{2}$ and autoclaved; $\mathrm{pH} 7 \cdot 5$ ) and sodium sulfide (degassed with $100 \% \mathrm{~N}_{2}$ and autoclaved; $\mathrm{pH} 7 \cdot 5$ ). The $\mathrm{pH}$ of the medium was adjusted to $6 \cdot 0$ with $\mathrm{HCl}$ at room temperature unless noted otherwise. These procedures after autoclaving were all performed in an anaerobic chamber under a gas phase of $100 \% \mathrm{~N}_{2}$. The anaerobic cultivation technique employed was that described by Balch \& Wolfe (1976). The medium was dispensed at $20 \%$ of the total volume of a bottle or tube, which was then sealed tightly with a butyl rubber stopper and the gas phase was exchanged with $\mathrm{N}_{2}$ at $200 \mathrm{kPa}$ for routine cultivation or with other gasses at $200 \mathrm{kPa}$ for testing the effect of the gas phase.

All experiments described below were conducted in duplicate. In an attempt to examine whether the oxidation and reduction of inorganic substances supported or stimulated growth, various nitrogen compounds $\left(\mathrm{NH}_{4} \mathrm{Cl}, \mathrm{NaNO}_{2}\right.$ and $\mathrm{NaNO}_{3}$ at 20 or $2 \mathrm{mM}$ ), various sulfur compounds $\left(\mathrm{Na}_{2} \mathrm{SO}_{4}\right.$, $\mathrm{Na}_{2} \mathrm{SO}_{3}, \mathrm{Na}_{2} \mathrm{~S}_{2} \mathrm{O}_{3}$ and $\mathrm{Na}_{2} \mathrm{~S}_{2} \mathrm{O}_{5}$ at 5 or $0.5 \mathrm{mM}, \mathrm{S}^{0}$ at $3 \%$ ) and various iron sulfide forms ( $\mathrm{FeS}, \mathrm{FeS}_{2}$ and $\mathrm{Fe}_{2} \mathrm{~S}_{3}$ at 5 or $0.5 \mathrm{mM}$ ) were used alone or in various combinations, instead of the combination of $\mathrm{NaNO}_{3}$ and $\mathrm{FeSO}_{4}$ of MJYP* medium, in the presence or absence of sodium sulfide.

In addition, the stimulation of growth by various metal sulfates $\left(\mathrm{CuSO}_{4}, \mathrm{NiSO}_{4}, \mathrm{MnSO}_{4}, \mathrm{CoSO}_{4}, \mathrm{ZnSO}_{4}\right.$ and $\mathrm{VSO}_{4}$ at $5 \mathrm{mM}$ ) was also examined in place of $\mathrm{FeSO}_{4}$ of MJYP* medium in the presence of sodium sulfide. To test the effect of $\mathrm{pH}$ on growth, the $\mathrm{pH}$ of MJYP* medium was adjusted to various values with $\mathrm{HCl}$ or $\mathrm{NaOH}$ at room temperature. The $\mathrm{pH}$ was found to be stable during the cultivation period. To test the effects of sea salt concentration on growth, varying dilutions of $2 \times \mathrm{MJ}(-\mathrm{N})$ synthetic sea water supplemented with $0.2 \%(\mathrm{w} / \mathrm{v})$ yeast extract, $0 \cdot 2 \%(\mathrm{w} / \mathrm{v})$ Trypticase peptone, $20 \mathrm{mM} \mathrm{NaNO}$ and $5 \mathrm{mM} \mathrm{FeSO}_{4}$ (pH 6.0) were used instead of MJYP* medium. Autotrophic growth was tested in $\mathrm{MJ}(-\mathrm{N})$ synthetic sea water containing $0.1 \%$ (w/v) $\mathrm{NaHCO}_{3}, 0 \cdot 1 \%$ (v/v) trace vitamin solution (Balch et al., 1979), $20 \mathrm{mM} \mathrm{NaNO}$ and either $5 \mathrm{mM} \mathrm{FeSO}_{4}$ or $3 \%$ (w/v) $\mathrm{S}^{0}(\mathrm{pH} 6.0)$ in the presence of sodium sulfide under a gas phase of $\mathrm{H}_{2} / \mathrm{CO}_{2}(80: 20,200 \mathrm{kPa})$ or $\mathrm{N}_{2} / \mathrm{CO}_{2}(80: 20$, 
$200 \mathrm{kPa}$ ) for anaerobic conditions and in the absence of sodium sulfide under a gas phase of $\mathrm{H}_{2} / \mathrm{CO}_{2} / \mathrm{N}_{2} / \mathrm{O}_{2}$ $(60: 10: 25: 5,200 \mathrm{kPa})$ for microaerobic conditions.

Effect of pressure on growth. The effect of hydrostatic pressure on growth was examined by using the 'DEEPBATH' system, a high-pressure/high-temperature bioreactor, as described previously (Moriya et al., 1995; Takai et al., 1999). Cells pre-cultured in MJYP* medium at $84^{\circ} \mathrm{C}$ were transferred to a 1.51 glass vessel containing 1 litre MJYP* medium, pre-heated to $84^{\circ} \mathrm{C}$ and pre-pressurized at $0 \cdot 1,10,20,30,40,50$ or $60 \mathrm{MPa}$ under a gas phase of $100 \%$ $\mathrm{N}_{2}$, which was then weakly agitated. For tests under hydrostatic pressures of $0 \cdot 1,10,20$ or $30 \mathrm{MPa}$, a sample precultured under the same hydrostatic pressure was used as the inoculum. In case of higher pressures $(40,50$ or $60 \mathrm{MPa})$, cells grown at $30 \mathrm{MPa}$ were used for the inocula. Samples were taken at regular intervals and growth under each pressure was determined by direct cell counting.

Organic substrates for growth. In an attempt to find organic substrates that could support growth of the isolate, experiments were conducted in which the yeast extract and Trypticase peptone in MJYP* medium were replaced with other organic materials as potential substrates. These were added at concentrations of 0.02 or $0.2 \%(\mathrm{w} / \mathrm{v})$. The cells were pre-cultured in each medium prior to inoculation of the same medium. These tests were performed in duplicate at $80{ }^{\circ} \mathrm{C}$.

Determination of growth. Growth of the new isolate was determined by direct cell counting after staining with $4^{\prime}, 6-$ diamidino-2-phenylindole (DAPI) (Porter \& Feig, 1980) using a Nikon Optishot microscope equipped with a Nikon FX-II camera system. Cultures were prepared in duplicate. The cells were grown in $100 \mathrm{ml}$ glass bottles (Schott Glaswerke), each containing $20 \mathrm{ml}$ medium, in a temperature-controlled dry oven (Taitec). The $\mathrm{pH}$ growth curve was determined at $80^{\circ} \mathrm{C}$ and the growth conditions for all other cultivation tests were $80^{\circ} \mathrm{C}$ and $\mathrm{pH} 6.0$ adjusted at room temperature, unless noted otherwise.

Antibiotic susceptibility. Susceptibility to the antibiotics vancomycin, streptomycin, chloramphenicol and rifampicin at final concentrations of 50,100 and $150 \mu \mathrm{g} \mathrm{m}{ }^{-1}$ was determined in MJYP* medium. Rhodothermus obamensis and Thermaerobacter marianensis were used as controls to check the effectiveness of the antibiotics at $80{ }^{\circ} \mathrm{C}$.

Light and electron microscopy. Cells were routinely observed under a phase-contrast microscope (Optishot 2; Nikon). For microscopy at $80{ }^{\circ} \mathrm{C}$, a drop of culture at $80{ }^{\circ} \mathrm{C}$ was placed on a slide preheated to $85^{\circ} \mathrm{C}$ and observed immediately. Micrographs were obtained by using a Nikon Optishot microscope equipped with a Nikon FX-II camera system. Transmission electron microscopy of negatively stained cells was carried out as described by Zillig et al. (1990). Cells grown in MJYP* medium at $80^{\circ} \mathrm{C}$ in the mid-exponential phase of growth were negatively stained with $2 \%(\mathrm{w} / \mathrm{v})$ uranyl acetate and observed under a JEOL JEM-1210 electron microscope at an accelerating voltage of $80 \mathrm{kV}$. For ultrathin sectioning, cells grown in MJYP* medium at $80^{\circ} \mathrm{C}$ in the mid-exponential phase of growth were fixed with $4 \%$ $(\mathrm{w} / \mathrm{v})$ paraformaldehyde for $1 \mathrm{~h}$ at room temperature. Thin sections were prepared and stained with uranyl acetate and lead citrate and observed with a JEOL JEM-1210 electron microscope at an accelerating voltage of $80 \mathrm{kV}$.

Techniques for analysis of inorganic metabolites. The concentrations of inorganic substances were monitored during growth of the isolate in MJYP medium supplemented with $5 \mathrm{mM} \mathrm{FeSO}_{4}\left(\mathrm{NaNO}_{3}\right.$-free $)$ or in $\mathrm{MJYP}^{*}$ medium $(20 \mathrm{mM}$ $\mathrm{NaNO}_{3}$ ) in the absence of sodium sulfide at $80^{\circ} \mathrm{C}$. The concentration of soluble ferrous iron was measured by using ferrozine (Lovley \& Phillips, 1986) and the concentration of soluble ferric iron was determined by the same method after reduction with $0.28 \mathrm{M}$ hydroxyl-ammonium chloride in a sample acidified with $1 \mathrm{M} \mathrm{HCl}$ and heated at $100{ }^{\circ} \mathrm{C}$ for 10 min; the ferrous iron concentration was subtracted. For cultivation on ferric iron-dependent medium, $10 \mathrm{mM}$ iron(III) citrate and poorly crystalline iron(III) oxide (10 mM) (Lovley \& Phillips, 1986) were added to MJYP medium without sodium sulfide. To monitor nitrate reduction, the diazotization method was employed to determine the concentration of nitrate/nitrite (Matsunaga \& Nishimura, 1969) and Nessler's reagent was employed to measure the ammonia concentration in the medium (Allen et al., 1974). The production of sulfite was checked by using a semi-quantitative test paper, Quantofix Sulphite (MachereyNagel). $\mathrm{H}_{2} \mathrm{~S}$ was analysed quantitatively by the methylene blue method (Fonselius, 1983) and $\mathrm{H}_{2}$ production was tested by using a $\mathrm{H}_{2}$ detection tube (GASTEC).

Lipid analysis. Core ether lipids were analysed by the modified whole-cell acid methanolysis method (De Rosa \& Gambacorta, 1988). Lyophilized cells (300 mg) were mixed with $1 \mathrm{ml}$ methanol containing $5 \%(\mathrm{w} / \mathrm{v}) \mathrm{HCl}$ and heated at $100{ }^{\circ} \mathrm{C}$ for $2 \mathrm{~h}$. Next, core lipids were extracted with $1 \mathrm{ml}$ chloroform and the sample was evaporated. The residue was dissolved in a small amount of chloroform and analysed by TLC on silica gel plates (Merck Kieselgel 60; Merck) developed in hexane/ethyl acetate $(7: 3, \mathrm{v} / \mathrm{v})$ or chloroform/ ethanol $(9: 1, \mathrm{v} / \mathrm{v})$. All compounds were visualized by spraying with $50 \%(\mathrm{w} / \mathrm{v})$ sulfuric acid, followed by heating at $160{ }^{\circ} \mathrm{C}$ for $5 \mathrm{~min}$. The intensity of coloured spots corresponding to each compound was measured by using a spectrophotoscanner (Shimadzu) and expressed as the integral optical density (IOD). Authentic core ether lipids extracted from Sulfolobus acidocaldarius were used as a reference.

Isolation and base composition of DNA. DNA was extracted and purified as described by Marmur \& Doty (1962) and Lauerer et al. (1986). The $\mathrm{G}+\mathrm{C}$ content of DNA was determined by direct analysis of deoxyribonucleotides by HPLC (Tamaoka \& Komagata, 1984). Nonmethylated DNA from bacteriophage $\lambda(\mathrm{G}+\mathrm{C}$ content $49.8 \mathrm{~mol} \%$; TaKaRa) (Sanger et al., 1982) was used as reference material.

Amplification of 16S rRNA gene and sequence determination. The 16S rRNA gene (rDNA) was amplified by the PCR using Arch 21F (Fuhrman et al., 1992) and 1492R (DeLong, 1992 ) primers. The $1.5 \mathrm{~kb}$ PCR product was sequenced directly by the dideoxynucleotide chain termination method using a DNA sequencer (model 373As; Perkin Elmer ABI). The rDNA sequence was analysed by using SIMILARITY_ RANK and ALIGN_SEQUENCE from the Ribosomal Database Project (RDP) (Larsen et al., 1993) and the gapped BLAST search algorithm (Altschul et al., 1997; Benson et al., 1998) to estimate the degree of similarity to other archaeal $16 \mathrm{~S}$ rDNA sequences.

Data analysis. The almost complete sequence (1409 bp) of $16 \mathrm{~S}$ rDNA of strain $\mathrm{DMJ}^{\mathrm{T}}$ was aligned manually to $16 \mathrm{~S}$ rDNA sequences from the RDP based on primary and secondary structure considerations by using the Genetic Data Environment (GDE) multiple-sequence editor. Phylogenetic analyses were restricted to nucleotide positions that were unambiguously alignable in all sequences. Least- 

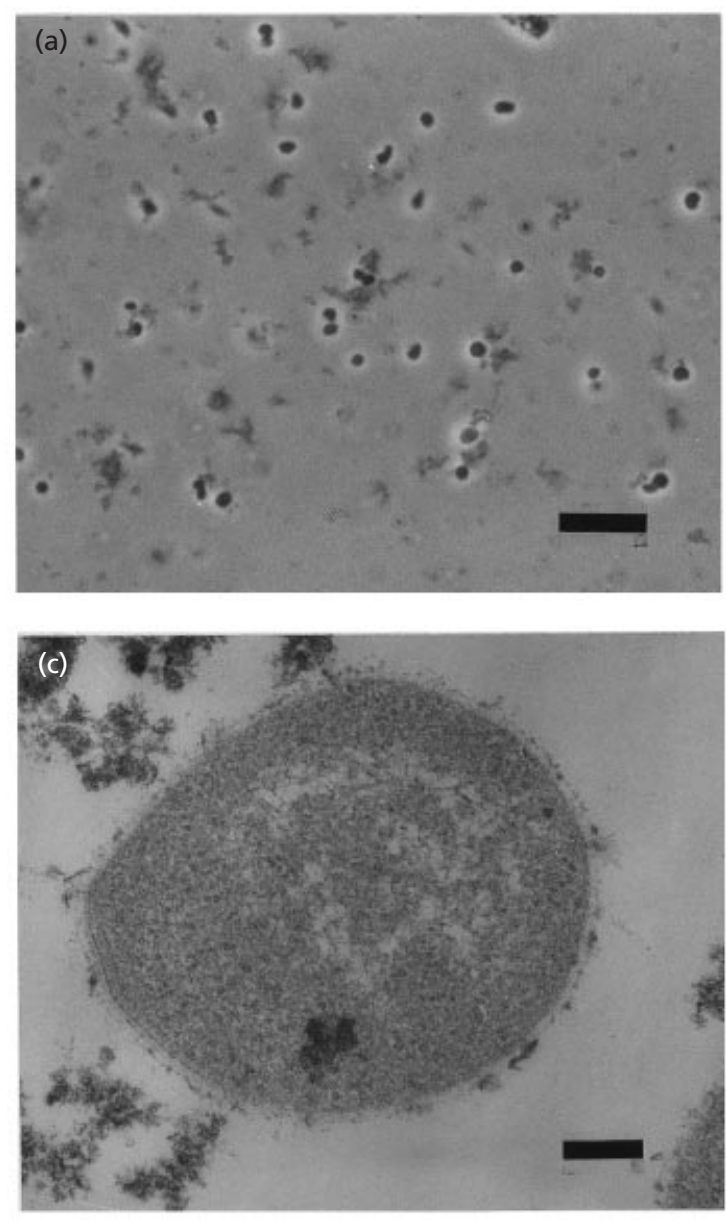

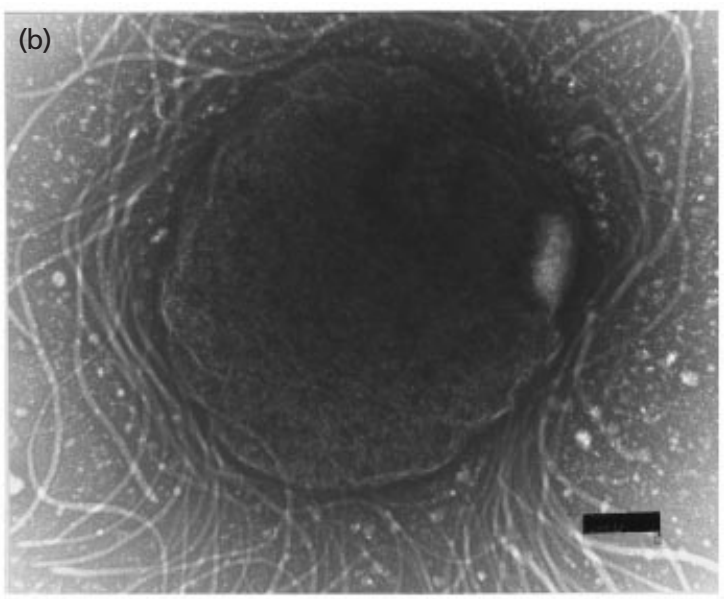

Fig. 1. Light and electron micrographs of Palaeococcus ferrophilus cells. (a) Phase-contrast micrograph of exponentially growing cells. Bar, $10 \mu \mathrm{m}$. (b) Electron micrograph of a negatively stained cell. Bar, $0.2 \mu \mathrm{m}$. (c) Electron micrograph of a thin section of an exponentially growing cell. Bar, $0.2 \mu \mathrm{m}$. squares distance matrix analysis (Olsen, 1988), based on evolutionary distances, was performed by using the correction of Kimura (1980). Neighbour-joining analysis was accomplished by using the ODEN software package (version 1.1, National Institute of Genetics, Mishima, Japan). Maximum-likelihood analysis was performed by using the PHYLIP package (version 3.5; obtained from J. Felsenstein, University of Washington, Seattle). Bootstrap analysis was used to provide confidence estimates for phylogenetic tree topologies.

Cultivation test. Representative members of the Thermococcales were cultivated in media containing various inorganic substances to examine the effect of iron on their growth. Pyrococcus species were cultivated at $95^{\circ} \mathrm{C}$ and Thermococcus species were cultivated at $80^{\circ} \mathrm{C}$ under a gas phase of $\mathrm{N}_{2}(100 \%, 200 \mathrm{kPa})$. The $\mathrm{pH}$ of all media was adjusted to 6.0 at room temperature.

\section{RESULTS}

\section{Enrichment and purification}

Enrichment from a black smoker chimney sample in MJYP* medium occurred at 75 and $84^{\circ} \mathrm{C}$, and only highly motile, irregular coccoid cells were observed after incubation for $2 \mathrm{~d}$. Although the cells could not form colonies in the tubes of MJYP* medium containing 2 or $3 \%(\mathrm{w} / \mathrm{v})$ agar (melting temperature
$80{ }^{\circ} \mathrm{C}$; Nacarai Tesque) at $75^{\circ} \mathrm{C}$, they were successfully purified by the dilution-to-extinction technique in 10 separate series at $75^{\circ} \mathrm{C}$. The culture in the tube showing growth at the highest dilution was designated strain $\mathrm{DMJ}^{\mathrm{T}}\left(=\mathrm{JCM} 10246^{\mathrm{T}}\right)$. The purity of this culture was confirmed routinely by microscopic examination and by repeated partial sequencing of the $16 \mathrm{~S}$ rRNA gene using several PCR primers. All further experiments were performed with isolate $\mathrm{DMJ}^{\mathrm{T}}$.

\section{Morphology}

The cells were irregular cocci, $0 \cdot 5-2 \cdot 0 \mu \mathrm{m}$ in diameter, often appearing singly or in pairs (Fig. 1a). As observed by light microscopy at $80^{\circ} \mathrm{C}$, the cells were highly motile, and transmission electron microscopic examination of negatively stained cells indicated that the cells had multiple flagella (Fig. 1b). Electron micrographs of thin sections indicated the presence of an $S$ layer-like structure (Fig. 1c). As described by Blöchl et al. (1997), the periplasmic space was little stained by the conventional method of chemical fixation and dehydration at room temperature (Fig. 1c). The dense layer in the outer part presumably revealed the heads of the $S$-layer-anchoring protein complexes (Baumeister \& Lembcke, 1992). 
Table 1. The effect of inorganic substances on growth of Palaeococcus ferrophilus

Cells were grown at $80^{\circ} \mathrm{C}$ under a gas phase of $\mathrm{N}_{2}(100 \%, 200 \mathrm{kPa})$ and the $\mathrm{pH}$ of all media was 6.0 at room temperature. MJYP, MJYP* and MJYPS media were described in Methods. Maximum cell yield is given as:,$++ 1 \times 10^{8}-5 \times 10^{8}$ cells $\mathrm{ml}^{-1}$ culture;,$+ 5 \times 10^{7}-1 \times 10^{8}$ cells $\mathrm{ml}^{-1}$ culture; - , no growth.

\begin{tabular}{|c|c|}
\hline Medium & $\begin{array}{c}\text { Maximum } \\
\text { cell yield }\end{array}$ \\
\hline 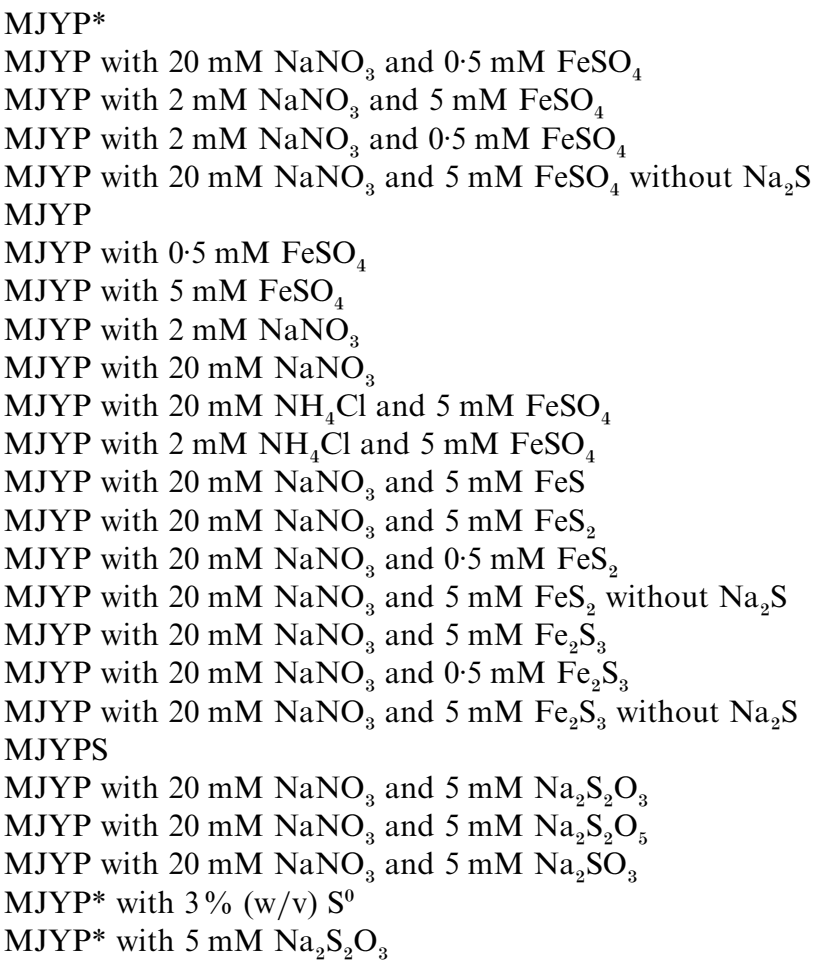 & $\begin{array}{c}++ \\
+ \\
+ \\
+ \\
++ \\
- \\
+ \\
++ \\
- \\
- \\
++ \\
++ \\
- \\
++ \\
++ \\
++ \\
++ \\
+ \\
++ \\
+\left(\mathrm{H}_{2} \mathrm{~S} \text { formed }\right) \\
- \\
- \\
- \\
+\left(\mathrm{H}_{2} \mathrm{~S} \text { formed }\right) \\
++\end{array}$ \\
\hline
\end{tabular}

\section{Antibiotic susceptibility}

The control bacteria Rhodothermus obamensis and Thermaerobacter marianensis exhibited the expected pattern of antibiotic susceptibility at $80^{\circ} \mathrm{C}$, indicating that the antibiotics used in this study were effective at this cultivation temperature. The new isolate was found to be resistant to vancomycin, streptomycin and chloramphenicol at $150 \mu \mathrm{g} \mathrm{ml}^{-1}$ and to rifampicin at $100 \mu \mathrm{g} \mathrm{ml}^{-1}$.

\section{Growth parameters}

The new isolate grew only under strictly anaerobic culture conditions (Table 1). The isolate was found to be a heterotroph; it did not grow under any of the autotrophic culture conditions tested. Under a $\mathrm{N}_{2}$ gas phase, growth on MJYP* medium, which contains $\mathrm{FeSO}_{4}$, was almost the same as growth on MJYPS, which contains $\mathrm{S}^{0}$. However, in the presence of $\mathrm{H}_{2}$, no growth was observed in MJYP* medium, whereas growth was unaffected on MJYPS medium. $\mathrm{H}_{2}$ was produced during growth in MJYP* medium, while
$\mathrm{H}_{2} \mathrm{~S}$ was detected as a major gas product during growth in MJYPS medium.

The isolate grew over the temperature range of about 60 to $88^{\circ} \mathrm{C}$, showing optimum growth at $83^{\circ} \mathrm{C}$, and the generation time at $83^{\circ} \mathrm{C}$ was about $30 \mathrm{~min}$ at pH 6.0 (Fig. 2a). No growth was observed at $90{ }^{\circ} \mathrm{C}$. Growth of the new isolate at $80{ }^{\circ} \mathrm{C}$ occurred between $\mathrm{pH} 4 \cdot 0$ and $8 \cdot 0$, with optimum growth at about $\mathrm{pH} 6 \cdot 0$ (Fig. 2b). No growth was detected below $\mathrm{pH} 4.0$ or above $\mathrm{pH} 8 \cdot 0$.

The new isolate required sea salts for growth. It grew over the concentration range of about 20 to $73 \mathrm{~g}$ sea salts $1^{-1}$, with optimum growth at around $43 \mathrm{~g}$ sea salts $1^{-1}$ at $80^{\circ} \mathrm{C}$ and $\mathrm{pH} 6.0$ (Fig. 2c). Below 20 or above $73 \mathrm{~g}$ sea salts $1^{-1}$, no growth was observed and the cells lysed rapidly.

The growth rate and cell yield of the isolate were enhanced at hydrostatic pressures of 30 and $10 \mathrm{MPa}$, respectively (Fig. 2d). These results indicated that the new isolate was a barophilic micro-organism with an optimum pressure for growth $(30 \mathrm{MPa})$ higher than 

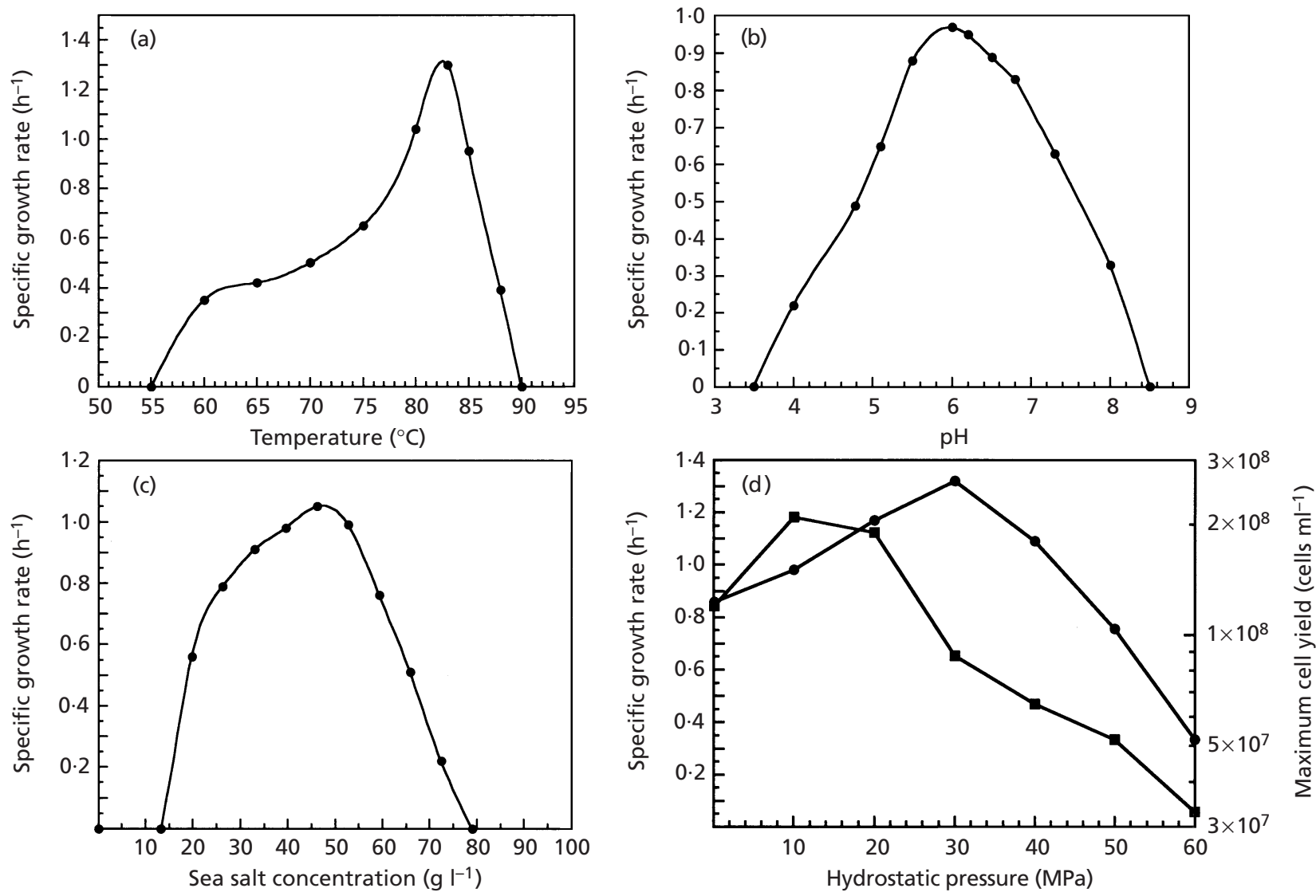

Fig. 2. Effects of temperature (a), pH (b), sea salt concentration (c) and hydrostatic pressure (d) on growth of Palaeococcus ferrophilus. (a) Growth was determined in MJYP* medium at pH 6.0. No growth occurred below $60^{\circ} \mathrm{C}$ or above $88^{\circ} \mathrm{C}$. (b) Growth was determined in MJYP* medium at $80^{\circ} \mathrm{C}$. The $\mathrm{pH}$ of the medium was adjusted with $\mathrm{HCl}$ or $\mathrm{NaOH}$ at room temperature. No growth occurred below $\mathrm{pH} 4.0$ or above $\mathrm{pH} 8.0$. (c) Growth was determined in varying dilutions of $2 \times \mathrm{MJ}(-\mathrm{N})$ synthetic sea water containing $0.2 \%(\mathrm{w} / \mathrm{v})$ yeast extract and $0.2 \%(\mathrm{w} / \mathrm{v})$ Trypticase peptone supplemented with $20 \mathrm{mM} \mathrm{NaNO}$ and $5 \mathrm{mM} \mathrm{FeSO}_{4}$ (pH 6.0), instead of MJYP* medium. No growth was observed at sea salt concentrations below 20 or above $73 \mathrm{~g} \mathrm{I}^{-1}$. (d) Growth rate (0) and maximum cell yield ( $\boldsymbol{\square}$ ) were determined by using the 'DEEP-BATH' system in MJYP* medium at $84^{\circ} \mathrm{C}$ and $\mathrm{pH} 6 \cdot 0$.

the in situ hydrostatic pressure $(13 \mathrm{MPa})$ at the isolation site. When the isolate was cultivated in MJYPS medium instead of MJYP* medium, the highest growth rate and cell yield were obtained at $30 \mathrm{MPa}$ (data not shown). In the 'DEEP-BATH' system (Moriya et al., 1995; Takai et al., 1999), the dissolution of gas components increases with increasing hydrostatic pressure. $\mathrm{H}_{2}$ was probably produced in the course of growth in the presence of $\mathrm{FeSO}_{4}$, and accumulation of $\mathrm{H}_{2}$ may have inhibited the subsequent growth of the isolate and reduced the final cell yield. Hence, the lower optimum pressure in terms of cell yield from the culture in the presence of $\mathrm{FeSO}_{4}$ may have been due to $\mathrm{H}_{2}$ accumulation.

\section{Inorganic and organic substrates}

Since the isolate did not grow in a medium consisting only of synthetic sea water and organic substrates such as yeast extract and Trypticase peptone, various inorganic substances were added to the medium to determine which served to support growth of the isolate as energy sources or growth factors (Table 1). The isolate was capable of growth using yeast extract and Trypticase peptone when $\mathrm{FeSO}_{4}, \mathrm{FeS}_{2}, \mathrm{Fe}_{2} \mathrm{~S}_{3}$ or $\mathrm{S}^{0}$ were added to the medium (Table 1). The presence of $\mathrm{NaNO}_{3}$ or $\mathrm{NH}_{4} \mathrm{Cl}$ was not required absolutely for growth of the isolate and no requirement for other inorganic substances was observed. In the presence of $\mathrm{S}^{0}, \mathrm{H}_{2} \mathrm{~S}$ was produced during growth, as determined by the methylene blue method, indicating that sulfur reduction was associated strongly with growth of the isolate. In contrast, $\mathrm{H}_{2}$ was produced during growth in the presence of $\mathrm{FeSO}_{4}, \mathrm{FeS}_{2}$ or $\mathrm{Fe}_{2} \mathrm{~S}_{3}$, while little $\mathrm{H}_{2} \mathrm{~S}$ was detected. The presence of both $\mathrm{S}^{0}$ and $\mathrm{FeSO}_{4}$ resulted in a somewhat lower cell yield (Table 1). When the new isolate was grown at varying concentrations of $\mathrm{FeSO}_{4}, \mathrm{FeS}_{2}$ or $\mathrm{Fe}_{2} \mathrm{~S}_{3}$, the maximum cell yield was increased with increasing concentration of each substrate (Fig. 3). This result also supported the conclusion that the new isolate required iron during growth in the absence of sulfur. 


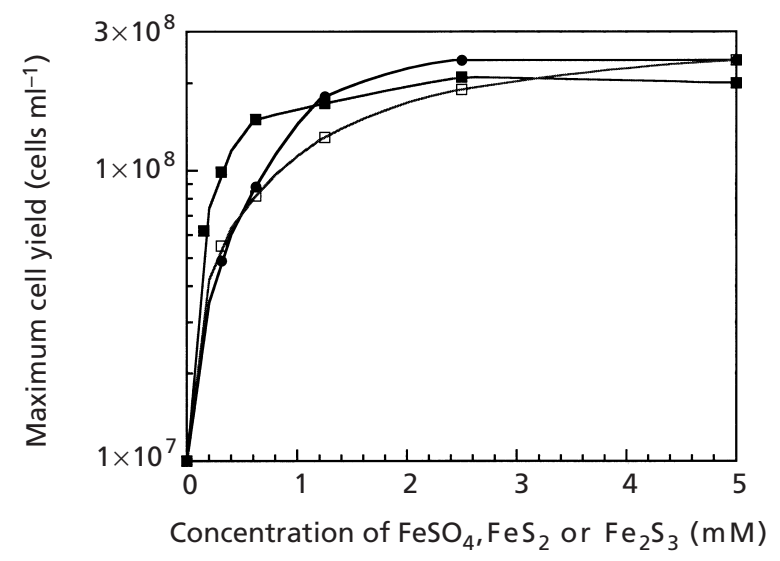

Fig. 3. Effect of concentration of $\mathrm{FeSO}_{4}(\mathbf{0}), \mathrm{FeS}_{2}(\boldsymbol{\square})$ or $\mathrm{Fe}_{2} \mathrm{~S}_{3}$ ( $\square$ ) on growth of Palaeococcus ferrophilus. The maximum cell yields were determined in MJYP medium containing $20 \mathrm{mM}$ $\mathrm{NaNO}_{3}$ and various concentrations of iron compounds at $80^{\circ} \mathrm{C}$ and $\mathrm{pH} 6 \cdot 0$.

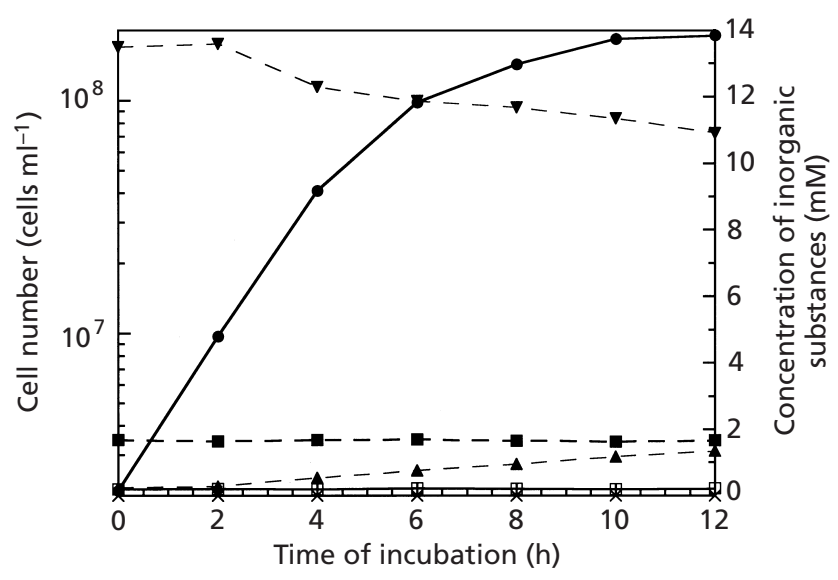

Fig. 4. Change in inorganic metabolites during growth of Palaeococcus ferrophilus. The cell number (0) and concentrations of $\mathrm{Fe}^{2+}(\boldsymbol{\nabla}), \mathrm{Fe}^{3+}(\square) \mathrm{NO}_{3}^{-}(\boldsymbol{\nabla}), \mathrm{NO}_{2}^{-}(\times)$and $\mathrm{NH}_{4}^{+}$ (A) were determined during the period of growth in MJYP* medium in the absence of sodium sulfide at $80^{\circ} \mathrm{C}$ and $\mathrm{pH} 6.0$.

In order to determine which form of iron, ferrous or ferric, was required for growth and how the iron functioned for growth, the concentrations of soluble ferrous and ferric iron in the medium were monitored during growth in the presence or absence of nitrate. When the cells were cultivated in MJYP medium supplemented with $5 \mathrm{mM} \mathrm{FeSO}{ }_{4}\left(\mathrm{NaNO}_{3}\right.$-free) in the absence of sodium sulfide, the concentrations of soluble ferrous and ferric iron were 1.4 and $0.2 \mathrm{mM}$ immediately after culture inoculation and were stable during the period of growth. In the case of the growth in MJYP* medium, the concentrations of soluble ferrous and ferric iron were maintained at their initial levels (1.6 mM and $0.2 \mathrm{mM}$ ) (Fig. 4). This result implied that iron was not associated with either ferrous iron oxidation or ferric iron reduction during growth. Although little production of ammonium ions was observed during growth on $\mathrm{NaNO}_{3}$-free medium, the ammonium ion concentration increased with decreasing nitrate ion concentration during growth on MJYP* medium (Fig. 4). The reduced nitrate ion concentration and the elevated ammonium ion concentration were not observed during incubation of uninoculated MJYP* medium. These results suggested that the new isolate was able to use nitrate as an electron acceptor and to form ammonium in the presence of iron, whereas nitrate reduction was not absolutely required for growth. In either medium in the absence or presence of $\mathrm{NaNO}_{3}, \mathrm{H}_{2}$ was produced during growth and no $\mathrm{H}_{2} \mathrm{~S}$ was detected.

To determine the effect of ferric iron on growth, the new isolate was cultivated in MJYP medium supplemented with $10 \mathrm{mM}$ iron(III) citrate or poorly crystalline iron(III) oxide (10 mM) without sodium sulfide (Lovley \& Phillips, 1986). However, no growth occurred on the medium containing ferric iron alone. The growth characteristics with various inorganic substances suggested strongly that the new isolate required either elemental sulfur or ferrous iron absolutely for growth. Because ferrous iron oxidation did not occur during growth, nitrate reduction was not associated with iron oxidation.

Organic substrates that served to support heterotrophic growth were determined in the presence of ferrous iron or elemental sulfur as cofactors for growth. In either case, the isolate grew only in media containing proteinaceous substrates such as yeast extract, Trypticase peptone, tryptone or casein. In addition, the maximum cell yield was enhanced by increased concentrations of these substrates. No growth occurred with starch, Casamino acids, any of various sugars (maltotriose, cellobiose, maltose, lactose, trehalose, sucrose, glucose, galactose, fructose or xylose), organic acids (tartrate, succinate, propionate, 2-aminobutyric acid, malate, lactate, pyruvate or acetate) or amino acids.

\section{Lipid analysis}

In common with other members of the Archaea, the isolate was found to have ether lipid membranes. The major core lipids were $\mathrm{C}_{40}$ tetraether lipids $(>80 \%)$ and a small proportion of $\mathrm{C}_{20}, \mathrm{C}_{20}$ diether lipids was also detected $(<20 \%)$.

\section{DNA base composition}

The $\mathrm{G}+\mathrm{C}$ content of the genomic DNA of strain $\mathrm{DMJ}^{\mathrm{T}}$ was found to be $53 \cdot 5 \mathrm{~mol} \%$.

\section{Phylogenetic analyses}

Almost the complete sequence (1409 bp) of the 16S rRNA gene was determined from strain $\mathrm{DMJ}^{\mathrm{T}}$. The $16 \mathrm{~S}$ rDNA sequence of the new isolate was determined 


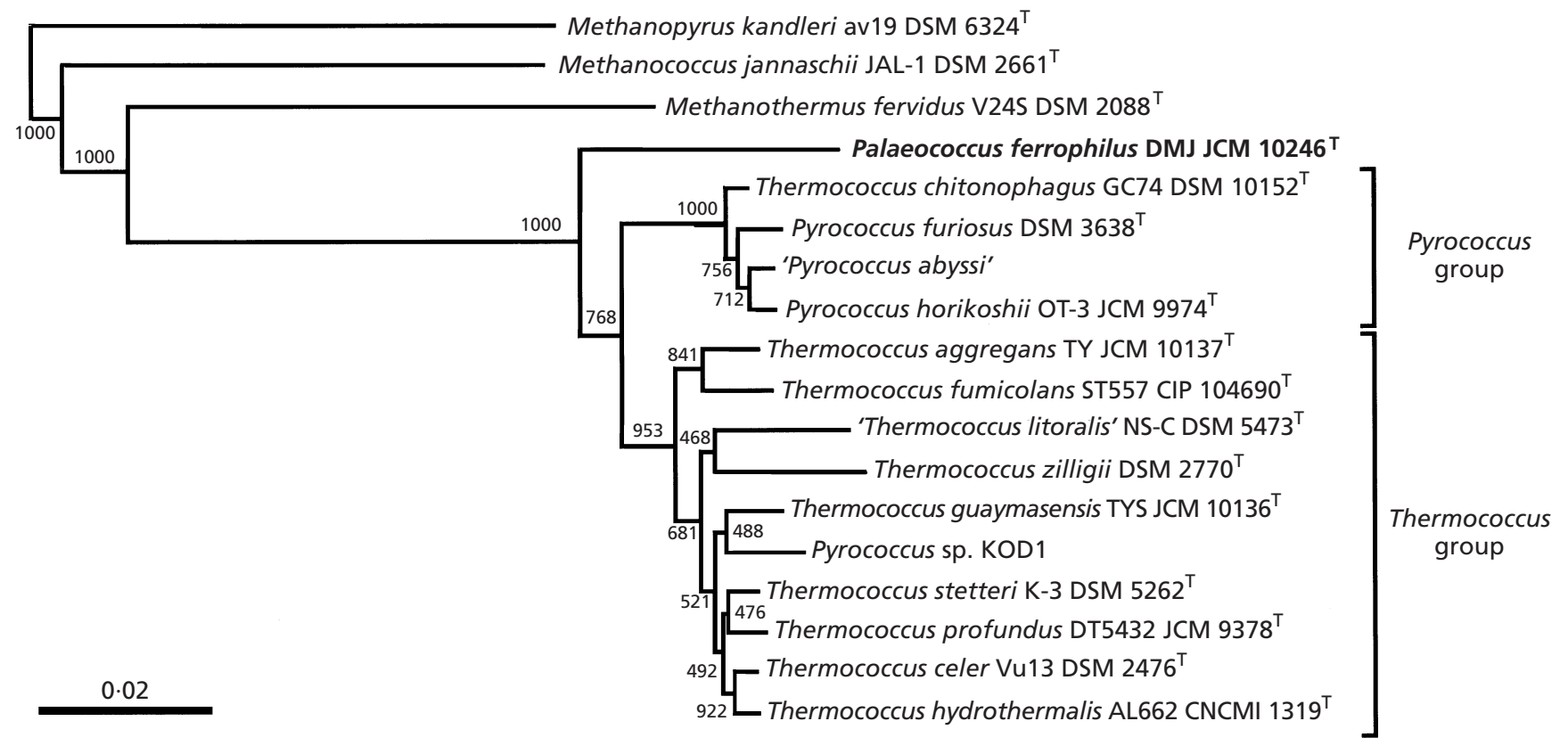

Fig. 5. Phylogenetic tree of representative members of the Thermococcales within the Euryarchaeota inferred by the neighbour-joining method from 16S rDNA sequences using 1229 homologous sequence positions for each organism. Each number represents the bootstrap value for branching (1000 replicates). The scale bar indicates two substitutions per 100 nucleotides. The 16S rDNA sequences in this figure are from GenBank with the accession numbers: Methanopyrus kandleri, M59932; Methanococcus jannaschii, M59126; Methanothermus fervidus, M32222; Pyrococcus furiosus, U20163; Pyrococcus horikoshii, D87344; 'Pyrococcus abyssi', L19921; Pyrococcus sp. KOD1, D38650; Thermococcus chitonophagus, X99570; Thermococcus aggregans, Y08384; Thermococcus fumicolans, Z70250; 'Thermococcus litoralis', Z70252; Thermococcus zilligii, U76534; Thermococcus guaymasensis, Y08384; Thermococcus stetteri, Z75240; Thermococcus profundus, Z75233; Thermococcus celer, M21529; Thermococcus hydrothermalis, Z70244; Palaeococcus ferrophilus, AB019239.

repeatedly to check culture purity and the reproducibility of PCR amplification of the rDNA sequence was confirmed. Furthermore, inspection of the predicted secondary structure and evaluation by the CHECK_chimera program of the RDP (Larsen et al., 1993) indicated that the rDNA sequence of $\mathrm{DMJ}^{\mathrm{T}}$ was free from chimeric artifacts (data not shown). The rDNA sequence of the isolate was most closely related to those of Thermococcus and Pyrococcus species, but showed less than $93 \%$ similarity to either of these genera $(92.9 \%$ to Thermococcus guaymasensis and Thermococcus profundus; $92.8 \%$ to Thermococcus celer $; 92.6 \%$ to Thermococcus stetteri, Thermococcus aggregans and Thermococcus hydrothermalis; 92.3\% to Thermococcus zilligii; $91.9 \%$ to 'Thermococcus litoralis'; $91.6 \%$ to Thermococcus fumicolans; $91.4 \%$ to Thermococcus chitonophagus; $92.5 \%$ to Pyrococcus sp. KOD1; $92.2 \%$ to Pyrococcus furiosus; $91.8 \%$ to Pyrococcus horikoshii and 'Pyrococcus abyssi'; 84.4\% to Methanothermus fervidus; $83.8 \%$ to Methanococcus jannaschii; $83.4 \%$ to Archaeoglobus fulgidus; $78.6 \%$ to Methanopyrus kandleri). These findings imply that the new isolate is a member of the order Thermococcales within the Euryarchaeota, even though the isolate appears to be phylogenetically distant from the two genera within the Thermococcales. For phylogenetic placement of the isolate, phylogenetic trees were constructed by the neighbour-joining and maximumlikelihood methods.

Phylogenetic analyses by the neighbour-joining and maximum-likelihood methods indicated exactly identical topologies in the affiliation of the new isolate, placing this organism prior to the divergence between Pyrococcus and Thermococcus (Fig. 5). On the basis of its phylogenetic placement, the new isolate is deemed to be a member of an ancient lineage of Thermococcales, representing a genus distinct from Pyrococcus and Thermococcus. The bootstrap confidence estimate also revealed high significance in the placement of strain $\mathrm{DMJ}^{\mathrm{T}}$ (Fig. 5).

\section{Cultivation test}

Representative members of the Thermococcales were cultivated in media containing various inorganic substances to examine the effect of iron on their growth (Table 2). Although all members of the Thermococcales including the new isolate grew in MJYPS medium, only Thermococcus stetteri and Thermococcus aggregans in addition to the new isolate grew on MJYP* medium (Table 2). These two species also grew on MJYP medium containing $20 \mathrm{mM} \mathrm{NaNO}$ and on other media without elemental sulfur or ferrous iron. The results indicated that these Thermococcus species 
Table 2. Comparison of the growth of members of the Thermococcales in various media

Pyrococcus species were cultivated at $95^{\circ} \mathrm{C}$ and Palaeococcus and Thermococcus species were cultivated at $80{ }^{\circ} \mathrm{C}$ under a gas phase of $\mathrm{N}_{2}(100 \%, 200 \mathrm{kPa})$. All media were based on MJYP medium containing $20 \mathrm{mM} \mathrm{NaNO}$. The various media were then supplemented with: A, no addition; $\mathrm{B}, 3 \% \mathrm{~S}^{0}$; C, $5 \mathrm{mM} \mathrm{FeSO}_{4}$; D, $5 \mathrm{mM} \mathrm{FeS}_{2}$; E, $5 \mathrm{mM} \mathrm{Fe}_{2} \mathrm{~S}_{3}$; F, $5 \mathrm{mM} \mathrm{FeS}$; G, $5 \mathrm{mM}$ $\mathrm{CuSO}_{4}, \mathrm{NiSO}_{4}, \mathrm{MnSO}_{4}, \mathrm{CoSO}_{4}$ or $\mathrm{VSO}_{4}$. The $\mathrm{pH}$ of all media was adjusted to 6.0 at room temperature. Maximum cell yield is given as:,$++ 1 \times 10^{8}-5 \times 10^{8}$ cells $\mathrm{ml}^{-1}$ culture; + , $5 \times 10^{7}-1 \times 10^{8}$ cells $\mathrm{ml}^{-1}$ culture; - , no growth.

\begin{tabular}{|c|c|c|c|c|c|c|c|}
\hline \multirow[b]{2}{*}{ Taxon } & \multicolumn{7}{|c|}{ Maximum cell yield } \\
\hline & $\mathbf{A}$ & B & $\mathbf{C}$ & D & $\mathbf{E}$ & $\mathbf{F}$ & $\mathbf{G}$ \\
\hline Palaeococcus ferrophilus & - & ++ & ++ & ++ & ++ & - & - \\
\hline Pyrococcus horikoshii & - & ++ & - & - & - & - & - \\
\hline Pyrococcus furiosus & - & ++ & - & - & - & - & - \\
\hline 'Pyrococcus abyssi' & - & ++ & - & - & - & - & - \\
\hline Thermococcus aggregans & ++ & ++ & ++ & ++ & ++ & ++ & ++ \\
\hline 'Thermococcus litoralis' & - & ++ & - & - & - & - & - \\
\hline Thermococcus guaymasensis & - & ++ & - & - & - & - & - \\
\hline Thermococcus stetteri & ++ & ++ & ++ & ++ & ++ & ++ & ++ \\
\hline Thermococcus peptonophilus & ++ & ++ & - & - & - & - & - \\
\hline Thermococcus profundus & - & ++ & - & - & - & - & - \\
\hline Thermococcus celer & - & ++ & - & - & - & - & - \\
\hline
\end{tabular}

were able to grow on media without elemental sulfur or ferrous iron and that the inorganic substances had little effect on their growth. An absolute requirement for ferrous iron was observed only in the new isolate among the members of the Thermococcales tested.

\section{DISCUSSION}

A novel barophilic, hyperthermophilic archaeon was isolated from a black smoker chimney at the Myojin Knoll in the Ogasawara-Bonin Arc, Japan. The isolate was found to be a strictly anaerobic, obligately heterotrophic micro-organism capable of growth using proteinaceous substrates such as yeast extract, peptone, tryptone and casein in the presence of either elemental sulfur $\left(\mathrm{S}^{0}\right)$ or ferrous iron $\left(\mathrm{Fe}^{2+}\right)$. The isolate produced $\mathrm{H}_{2} \mathrm{~S}$ when cultivated in the presence of $\mathrm{S}^{0}$ or in the presence of both $\mathrm{S}^{0}$ and $\mathrm{Fe}^{2+}$, while it produced $\mathrm{H}_{2}$ during growth in the presence of $\mathrm{Fe}^{2+}$. These features of fermentative-type metabolism are similar to those displayed by members of the Thermococcales, most of which are capable of growth using peptides in the presence or absence of $S^{0}$ (Zillig et al., 1983; Fiala \& Stetter, 1986; Miroshnichenko et al., 1989; Pledger \& Baross, 1989, 1991; Neuner et al., 1990; Gonzalez et al., 1995, 1998; Godfroy et al., 1996, 1997; Antoine et al., 1997; Canganella et al., 1997). The major core lipids of the new isolate were tetraether and diether lipids, which are the most predominant core lipids in the Thermococcales (Zillig et al., 1983; Pledger \& Baross, 1991; Godfroy et al., 1996, 1997; Gonzalez et al., 1998), and the 16S rDNA sequence was most closely related to those of members of the Thermococcales (Fig. 5). However, the representative species of the Thermococcales tested did not exhibit an absolute dependence on ferrous iron for growth in the absence of sulfur (Table 2). This is the first report of a member of the Thermococcales displaying an absolute requirement for ferrous iron for fermentative growth in the absence of sulfur. Phylogenetic analysis revealed that the new isolate is most closely related to members of the Thermococcales, representing an ancient lineage distinct from Pyrococcus and Thermococcus. Although most of the morphological and physiological properties of the new isolate were similar to those of other members of the Thermococcales, it seemed likely that the absolute requirement of the new isolate for ferrous iron for fermentative growth in the absence of sulfur was one of the discriminative properties. Furthermore, the phylogenetic position of the new isolate should be considered as important evolutionary evidence that discriminates the new isolate clearly from other members of the Thermococcales at the genus level. Therefore, we propose a new genus, Palaeococcus gen. nov. The type species is Palaeococcus ferrophilus sp. nov., of which the type strain is strain $\mathrm{DMJ}^{\mathrm{T}}(=\mathrm{JCM}$ $\left.10246^{\mathrm{T}}\right)$.

Recently, there has been increasing interest in the role of iron in early microbial metabolism in view of geochemical and microbiological findings (Walker, 1987; Ehlich, 1990; Cairns-Smith et al., 1992; Seyfried \& Mottl, 1995; Hafenbradl et al., 1996; Slobodkin et al., 1997; Slobodkin \& Wiegel, 1997; Vargas et al., 1998). Vargas et al. (1998) have demonstrated that many hyperthermophilic archaea and bacteria can reduce ferric iron and conserve energy to support growth. They have also suggested that not only sulfur- 
reducing hyperthermophiles but also those that grow by fermentation are capable of using ferric iron as a terminal electron acceptor (Vargas et al., 1998). Hafenbradl et al. (1996) isolated the first hyperthermophilic archaeon found to be capable of oxidizing ferrous iron anaerobically at neutral $\mathrm{pH}$, from a shallow marine hydrothermal vent environment, an organism named Ferroglobus placidus. On the basis of its metabolic properties, it has been speculated that the formation of ferric iron by such unique microorganisms under anaerobic conditions might have contributed to banded iron formation in the early history of the Earth (Hafenbradl et al., 1996). Compared with these iron-reducing or iron-oxidizing hyperthermophiles, Palaeococcus ferrophilus requires ferrous iron for fermentative growth but does not utilize iron as an electron acceptor or donor. In the fermentative-type metabolism of Thermococcus and Pyrococcus species, $\mathrm{S}^{0}$ reduction is thought to be a mechanism for detoxifying inhibitory $\mathrm{H}_{2}$ (Fiala \& Stetter, 1986), or it may play a role in energy conservation (Schicho et al., 1993). Ma et al. (1995) have reported that the production of $\mathrm{H}_{2}$ and some alcohols is increased because of the enhanced activities of iron hydrogenase and iron-alcohol dehydrogenase when Thermococcus sp. ES1 is cultivated under $\mathrm{S}^{0}$ limited conditions. These enzymes are thought to function in the disposal of excess reductant and may play an important role in $\mathrm{S}^{0}$-limited growth (Ma et al., 1995). Likewise, Palaeococcus ferrophilus produces $\mathrm{H}_{2} \mathrm{~S}$ when cultivated in the presence of $\mathrm{S}^{0}$ but $\mathrm{H}_{2}$ is produced instead during growth in the presence of $\mathrm{Fe}^{2+}$. It seems likely, therefore, that there are several enzymes, such as iron hydrogenase and iron-alcohol dehydrogenase in Thermococcus sp. ES1, that are regulated by ferrous iron, and relatively high concentrations of ferrous iron might be required for proper operation of the iron(II)-regulated fermentation pathway in Palaeococcus ferrophilus. Considering that iron is one of the most abundant chemical materials in the black smoker fluids and chimneys (Seyfried \& Mottl, 1995), iron could play a key role in the fermentative metabolism of organisms inhabiting black smoker environments, such as Palaeococcus ferrophilus. Further investigation of the function of ferrous iron in Palaeococcus ferrophilus may shed light on an as yet undiscovered role of iron in early microbial metabolism besides its function as an electron donor/ acceptor.

\section{Description of Palaeococcus gen. nov.}

Palaeococcus (Pa.la.eo.coc'cus. Gr. adj. palaios ancient; Gr. n. kokkos grain or kernel; M.L. masc. n. Palaeococcus ancient spherical cell, denoting the ancient lineage of this organism).

Irregular coccoid, highly motile with multiple flagella. Anaerobic, barophilic and hyperthermophilic. Neutrophilic heterotroph. Requirement for sea salts for growth. Able to utilize proteinaceous substrates such as yeast extract, peptone, tryptone and casein in the presence of elemental sulfur $\left(\mathrm{S}^{0}\right)$ or ferrous iron $\left(\mathrm{Fe}^{2+}\right)$ as a cofactor for growth. $\mathrm{G}+\mathrm{C}$ content of genomic DNA is about $54 \mathrm{~mol} \%$. Major core lipids are $\mathrm{C}_{40}$ tetraether and $\mathrm{C}_{20}$ diether lipids. On the basis of $16 \mathrm{~S}$ rRNA gene analysis, the genus Palaeococcus is most closely related to the genera Pyrococcus and Thermococcus and is a member of the order Thermococcales. Members of the genus Palaeococcus occur in deep-sea hydrothermal vent environments, so-called 'black smoker' environments. The type species is Palaeococcus ferrophilus.

\section{Description of Palaeococcus ferrophilus sp. nov.}

Palaeococcus ferrophilus (fer.ro'phi.lus. L. n. ferrum iron; Gr. adj. philos loving; M.L. adj. ferrophilus ironloving, indicating that it requires iron for growth in the absence of sulfur).

Irregular cocci, $0 \cdot 5-2 \cdot 0 \mu \mathrm{m}$ in diameter. Cells occur singly or in pairs. Exhibits high motility with multiple flagella. Strictly anaerobic. The temperature range for growth is $60-88{ }^{\circ} \mathrm{C}$ with the optimum being $83{ }^{\circ} \mathrm{C}$. The $\mathrm{pH}$ range for growth is from $4 \cdot 0$ to $8 \cdot 0$, with optimum growth occurring at $\mathrm{pH} \mathrm{6.0.} \mathrm{Sea} \mathrm{salts} \mathrm{in} \mathrm{the} \mathrm{con-}$ centration range of 20-73 $\mathrm{g} \mathrm{l}^{-1}$ are required for growth, with optimum growth occurring at $43 \mathrm{~g} \mathrm{l}^{-1}$. The optimum hydrostatic pressure for growth is $30 \mathrm{MPa}$. Growth using yeast extract, peptone, tryptone or casein occurs in the presence of elemental sulfur $\left(S^{0}\right)$ or ferrous iron $\left(\mathrm{Fe}^{2+}\right)$ as a required cofactor. Major core lipids are $\mathrm{C}_{40}$ tetraether $(>80 \%)$ and $\mathrm{C}_{20}$ diether lipids $(<20 \%)$. The $\mathrm{G}+\mathrm{C}$ content of genomic DNA is about $53.5 \mathrm{~mol} \%$ (HPLC). The $16 \mathrm{~S}$ rDNA sequence exhibits $93 \%$ similarity to those of members of the genera Pyrococcus and Thermococcus. The organism was isolated from a black smoker sample obtained from the Myojin Knoll in the Ogasawara-Bonin Arc, Japan, at a depth of $1338 \mathrm{~m}$.

The type strain of Palaeococcus ferrophilus is strain $\mathrm{DMJ}^{\mathrm{T}}$, which has been deposited in the Japan Collection of Microorganisms, Institute of Physical and Chemical Research (RIKEN), Wako-shi, Saitama, Japan, under accession number JCM $10246^{\mathrm{T}}$.

\section{ACKNOWLEDGEMENTS}

We would like to thank Dr Katsuyuki Uematsu for assistance in preparing electron micrographs and Dr Wayne R. Bellamy for editing English usage in the manuscript. This work was supported in part by a domestic research fellowship provided by the Japan Science and Technology Corporation.

\section{REFERENCES}

Achenbach-Richter, L., Gupta, R., Stetter, K. O. \& Woese, C. R. (1987). Were the original eubacteria thermophiles? Syst Appl Microbiol 9, 34-39.

Allen, S. E., Grimshaw, H. M., Parkinson, J. A. \& Quarmby, C. 
(1974). Inorganic constituents: nitrogen. In Chemical Analysis of Ecological Materials, pp. 184-206. Edited by S. E. Allen. London: Blackwell Scientific.

Altschul, S. F., Madden, T. L., Schäffer, A. A., Zhang, J., Zhang, Z., Miller, W. \& Lipman, D. J. (1997). Gapped BLAST and PSI-BLAST: a new generation of protein database search programs. Nucleic Acids Res 25, 3389-3402.

Antoine, E., Cilia, V., Meunier, J. R., Guezennec, J., Lesongeur, F. \& Barbier, G. (1997). Thermosipho melanesiensis sp. nov., a new thermophilic anaerobic bacterium belonging to the order Thermotogales, isolated from deep-sea hydrothermal vents in the Southwestern Pacific Ocean. Int J Syst Bacteriol 47, 1118-1123.

Balch, W. E. \& Wolfe, R.S. (1976). New approach to the cultivation of methanogenic bacteria: 2-mercaptoethanesulfonic acid (HS-CoM)-dependent growth of Methanobacterium ruminantium in a pressurized atmosphere. Appl Environ Microbiol 32, 781-791.

Balch, W. E., Fox, G. E., Magrum, L. J., Woese, C. R. \& Wolfe, R. S. (1979). Methanogens: reevaluation of a unique biological group. Microbiol Rev 43, 260-296.

Baross, J. A. (1995). Isolation, growth, and maintenance of hyperthermophiles. In Archaea, a Laboratory Manual. Thermophiles, pp. 15-23. Edited by F. T. Robb \& A. R. Place. Cold Spring Harbor, NY: Cold Spring Harbor Laboratory.

Baumeister, W. \& Lembcke, G. (1992). Structural features of archaebacterial cell envelopes. J Bioenerg Biomembr 24, 567-575.

Benson, D. A., Boguski, M. S., Lipman, D. J., Ostell, J. \& Ouellette, B. F. F. (1998). GenBank. Nucleic Acids Res 26, 1-7.

Blöchl, E., Rachel, R., Burggraf, S., Hafenbradl, D., Jannasch, H. W. \& Stetter, K. O. (1997). Pyrolobus fumarii, gen. and sp. nov., represents a novel group of archaea, extending the upper temperature limit for life to $113{ }^{\circ} \mathrm{C}$. Extremophiles 1, 14-21.

Burggraf, S., Jannasch, H. W., Nicolaus, B. \& Stetter, K. O. (1990). Archaeoglobus profundus sp. nov., represents a new species within the sulfate-reducing archaebacteria. Syst Appl Microbiol 13, 24-28.

Cairns-Smith, A. G., Hall, A. J. \& Rusell, M. J. (1992). Mineral theories of the origin of life and iron sulfide example. Origins Life Evol Biosphere 22, 161-180.

Canganella, F., Jones, W. J., Gambacorta, A. \& Antranikian, G. (1997). Biochemical and phylogenetic characterization of two novel deep-sea Thermococcus isolates with potentially biotechnological applications. Arch Microbiol 167, 233-238.

DeLong, E. F. (1992). Archaea in coastal marine environments. Proc Natl Acad Sci USA 89, 5685-5689.

De Rosa, M. \& Gambacorta, A. (1988). The lipids of archaebacteria. Prog Lipid Res 27, 153-175.

Ehlich, H. L. (1990). Geomicrobiology. New York: Marcel Dekker.

Fiala, G. \& Stetter, K. O. (1986). Pyrococcus furiosus sp. nov., represents a novel genus of marine heterotrophic archaebacteria growing optimally at $100^{\circ} \mathrm{C}$. Arch Microbiol 145, 56-61.

Fiala, G., Stetter, K. O., Jannasch, H. W., Langworthy, T. A. \& Madon, J. (1986). Staphylothermus marinus sp. nov., represents a novel genus of extremely thermophilic submarine heterotrophic archaebacteria growing up to $98{ }^{\circ} \mathrm{C}$. Syst Appl Microbiol 8, 106-113.

Fonselius, S. H. (1983). Determination of hydrogen sulfide. In Sea Water Analysis, pp. 73-80. Edited by K. Grasshoff, M. Ehrhardt \& K. Kremling. Weinheim: Verlag Chemie.
Fuhrman, J. A., McCallum, K. \& Davis, A. A. (1992). Novel major archaebacterial group from marine plankton. Nature 356, 148-149.

Godfroy, A., Meunier, J.-R., Guezennec, J., Lesongeur, F., Raguénès, G., Rimbault, A. \& Barbier, G. (1996). Thermococcus fumicolans sp. nov., a new hyperthermophilic archaeon isolated from a deep-sea hydrothermal vent in the North Fiji Basin. Int $J$ Syst Bacteriol 46, 1113-1119.

Godfroy, A., Lesongeur, F., Raguénès, G., Quérellou, J., Antoine, E., Meunier, J.-R., Guezennec, J. \& Barbier, G. (1997). Thermococcus hydrothermalis sp. nov., a new hyperthermophilic archaeon isolated from a deep-sea hydrothermal vent. Int J Syst Bacteriol 47, 622-626.

Gonzalez, J. M., Kato, C. \& Horikoshi, K. (1995). Thermococcus peptonophilus sp. nov., a fast-growing, extremely thermophilic archaebacterium isolated from deep-sea hydrothermal vents. Arch Microbiol 164, 159-164.

Gonzalez, J. M., Masuchi, Y., Robb, F. T., Ammerman, J. W., Maeder, D. L., Yanagibayashi, M., Tamaoka, J. \& Kato, C. (1998). Pyrococcus horikoshii sp. nov., a hyperthermophilic archaeon isolated from a hydrothermal vent at the Okinawa Trough. Extremophiles 2, 123-130.

Hafenbradl, D., Keller, M., Dirmeier, R., Rachel, R., Rossnagel, P., Burggraf, S., Huber, H. \& Stetter, K. O. (1996). Ferroglobus placidus gen. nov., sp. nov., a novel hyperthermophilic archaeaum that oxidizes $\mathrm{Fe}^{2+}$ at neutral $\mathrm{pH}$ under anoxic conditions. Arch Microbiol 166, 308-314.

Huber, R., Kurr, M., Jannasch, H. W. \& Stetter, K. O. (1989). A novel group of abyssal methanogenic archaebacteria (Methanopyrus) growing at $110^{\circ} \mathrm{C}$. Nature 342, 833-834.

Huber, H., Jannasch, H. W., Rachel, R., Fuchs, T. \& Stetter, K. O. (1997). Archaeoglobus veneficus sp. nov., a novel facultative chemolithoautotrophic hyperthermophilic sulfite reducer, isolated from abyssal black smokers. Syst Appl Microbiol 20, 374-380.

Jannasch, H. W., Wirsen, C. O., Molyneaux, S. J. \& Langworthy, T. A. (1988). Extremely thermophilic archaebacteria of the genus Desulfurococcus from deep-sea hydrothermal vents. Appl Environ Microbiol 54, 1203-1209.

Jones, W. J., Leigh, J. A., Mayer, F., Woese, C. R. \& Wolfe, R. S. (1983). Methanococcus jannaschii sp. nov., an extremely thermophilic methanogen from a submarine hydrothermal vent. Arch Microbiol 136, 254.

Kimura, M. (1980). A simple method for estimating evolutionary rates of base substitutions through comparative studies of nucleotide sequence. J Mol Evol 16, 111-120.

Larsen, N., Olsen, G. J., Maidak, B. L., McCaughey, M. J., Overbeek, R., Macke, T. J., Marsh, T. L. \& Woese, C. R. (1993). The ribosomal database project. Nucleic Acids Res 21, 3021-3023.

Lauerer, G., Kristjansson, J. K., Langworthy, T. A., Konig, H. \& Stetter, K. O. (1986). Methanothermus sociabilis sp. nov., a second species within the Methanothermaceae growing at $97{ }^{\circ}$ C. Syst Appl Microbiol 8, 100-105.

Lovley, D. R. \& Phillips, E. J. P. (1986). Organic matter mineralization with reduction of ferric iron in anaerobic sediments. Appl Environ Microbiol 51, 683-689.

Ma, K., Loessner, H., Heider, J., Johnson, M. K. \& Adams, M. W. W. (1995). Effects of elemental sulfur on the metabolism of the deep-sea hyperthermophilic archaeon Thermococcus strain ES-1: characterization of a sulfur-regulated, non-heme iron alcohol dehydrogenase. J Bacteriol 177, 4748-4756.

Marmur, J. \& Doty, P. (1962). Determination of the base 
composition of deoxyribonucleic acid from its thermal denaturation temperature. $J$ Mol Biol 5, 109-118.

Matsunaga, K. \& Nishimura, M. (1969). Determination of nitrate in sea water. Anal Chim Acta 43, 350-353.

Miroshnichenko, M. L., Bonch-Osmolovskaya, E. A., Neuner, A., Kostrikina, N. A., Chernych, N. A. \& Alekseev, V. A. (1989). Thermococcus stetteri sp. nov., a new extremely thermophilic marine archaebacteria. Syst Appl Microbiol 12, 257-262.

Moriya, K., Inada, T., Kyo, M. \& Horikoshi, K. (1995). Large-scale fermentation under high hydrostatic pressure using a newly developed deep-sea baro/thermophilic collection and cultivation system. J Mar Biotechnol 2, 175-177.

Neuner, A., Jannasch, H. W., Belkin, S. \& Stetter, K. O. (1990). Thermococcus litoralis sp. nov., a new species of extremely thermophilic marine archaebacteria. Arch Microbiol 153, 205-207.

Olsen, G. J. (1988). Phylogenetic analysis using ribosomal RNA. Methods Enzymol 164, 793-812.

Pledger, R. J. \& Baross, J. A. (1989). Characterization of an extremely thermophilic archaebacterium isolated from a black smoker polychaete (Paralvinella sp.) at the Juan de Fuca Ridge. Syst Appl Microbiol 12, 249-256.

Pledger, R. J. \& Baross, J. A. (1991). Preliminary description and nutritional characterization of a chemoorganotrophic archaeobacterium growing at temperatures of up to $110^{\circ} \mathrm{C}$ isolated from a submarine hydrothermal vent environment. $J$ Gen Microbiol 137, 203-211.

Pley, U., Schipka, J., Gambacorta, A., Jannasch, H. W., Fricke, H., Rachel, R. \& Stetter, K. O. (1991). Pyrodictium abysii sp. nov., represents a novel heterotrophic marine archaeal hyperthermophile growing at $110^{\circ} \mathrm{C}$. Syst Appl Microbiol 14, 245-253.

Porter, K. G. \& Feig, Y. S. (1980). The use of DAPI for identifying and counting microflora. Limnol Oceanograph 25, 943-948.

Prieur, D., Erauso, G. \& Jeanthon, C. (1995). Hyperthermophilic life at deep-sea hydrothermal vents. Planet Space Sci 43, $115-121$

Sako, Y., Takai, K., Ishida, Y., Uchida, A. \& Katayama, Y. (1996). Rhodothermus obamensis sp. nov., a modern lineage of extremely thermophilic marine bacteria. Int J Syst Bacteriol 46, 1099-1104.
Sanger, F., Coulson, A. R., Hong, G. F., Hill, O. F. \& Petersen, G. B. (1982). Nucleotide sequence of bacteriophage $\lambda$ DNA. $J \mathrm{Mol}$ Biol 162, 729-773.

Schicho, R. N., Ma, K., Adams, M. W. W. \& Kelly, R. M. (1993). Bioenergetics of sulfur reduction in the hyperthermophilic archaeon Pyrococcus furiosus. J Bacteriol 175, 1823-1830.

Seyfried, W. E., Jr \& Mottl, M. J. (1995). Geologic setting and chemistry of deep-sea hydrothermal vents. In The Microbiology of Deep-Sea Hydrothermal Vents, pp. 1-34. Edited by D. M. Karl. Boca Raton, FL: CRC Press.

Slobodkin, A. I. \& Wiegel, J. (1997). Fe(III) as an electron acceptor for $\mathrm{H}_{2}$ oxidation in thermophilic anaerobic enrichment cultures from geothermal areas. Extremophiles 1, 106-109.

Slobodkin, A., Reysenbach, A.-L., Strutz, N., Dreier, M. \& Wiegel, J. (1997). Thermoterrabacterium ferrireducens gen. nov., sp. nov., a thermophilic anaerobic dissimilatory Fe(III)-reducing bacterium from a continental hot spring. Int J Syst Bacteriol 47, 541-547.

Stetter, K. O., Fiala, G., Huber, G., Huber, R. \& Segerer, A. (1990). Hyperthermophilic microorganisms. FEMS Microbiol Rev 75, 117-124.

Takai, K., Inoue, A. \& Horikoshi, K. (1999). Thermaerobacter marianensis gen. nov., sp. nov., an aerobic extremely thermophilic marine bacterium from the $11000 \mathrm{~m}$ deep Mariana Trench. Int J Syst Bacteriol 49, 619-628.

Tamaoka, J. \& Komagata, K. (1984). Determination of DNA base composition by reversed-phase high-performance liquid chromatography. FEMS Microbiol Lett 25, 125-128.

Vargas, M., Kashefi, K., Blunt-Harris, E. L. \& Lovley, D. R. (1998). Microbiological evidence for Fe(III) reduction on early Earth. Nature 395, 65-67.

Walker, J. C. G. (1987). Was the Archaean biosphere upside down? Nature 329, 710-712.

Zillig, W., Holz, I., Janekovic, D., Schafer, W. \& Reiter, W. D. (1983). The archaebacterium Thermococcus celer represents a novel genus within the thermophilic branch of the archaebacteria. Syst Appl Microbiol 4, 88-94.

Zillig, W., Holz, I., Janekovic, D. \& 7 other authors (1990). Hyperthermus butylicus, a hyperthermophilic sulfur-reducing archaebacterium that ferments peptides. $J$ Bacteriol 172, 3959-3965. 